\title{
Geographic distribution of the invasive mealybug Phenacoccus manihoti and its introduced parasitoid Anagyrus lopezi in parts of Indonesia
}

\author{
MUHAMMAD ZAINAL FANANI ${ }^{1, \bullet}$, AUNU RAUF ${ }^{2}$, NINA MARYANA ${ }^{2}$, ALI NURMANSYAH ${ }^{2}$, \\ DADAN HINDAYANA ${ }^{2}$ \\ ${ }^{1}$ Program of Entomology, School of Graduates, Institut Pertanian Bogor. Jl. Raya Dramaga, Campus of IPB University, Bogor 16680, West Java, \\ Indonesia. Tel.: +62-251-8629364, Fax.: +62-251-8629362, ^email: muhammaduzainale@ gmail.com \\ ${ }^{2}$ Department of Plant Protection, Faculty of Agriculture, Institut Pertanian Bogor. Jl. Kamper, Dramaga Campus of IPB University, Bogor 16680, West \\ Java, Indonesia
}

Manuscript received: 9 October 2019. Revision accepted: 26 November 2019.

\begin{abstract}
Fanani Z. M., Rauf A, Maryana N, Nurmansyah A, Hindayana D. 2019. Geographic distribution of the invasive mealybug Phenacoccus manihoti and its introduced parasitoid Anagyrus lopezi in parts of Indonesia. Biodiversitas 20: 3751-3757. Cassava mealybug, Phenacoccus manihoti Matile-Ferrero (Hemiptera: Pseudococcidae), is an invasive pest detected for the first time in Indonesia in 2010. An exotic parasitoid Anagyrus lopezi (De Santis) (Hymenoptera: Encyrtidae) was introduced and released in 2014 to control the pest. Study was conducted with the objective to determine the geographic distribution of P. manihoti and spread of A. lopezi. Field surveys were conducted on cassava fields in various locations in Lampung, Java, and Nusa Tenggara. Our studies showed that $P$. manihoti was found to be widely distributed in Lampung, Banten, West Java, Central Java, East Java, West Nusa Tenggara and East Nusa Tenggara. In each location visited, symptoms of $P$. manihoti infestation as indicated by internode distortion and bunchy top were prominent. Three years following release, parasitoid A. lopezi has established and spread into several cassava growing areas, except East Nusa Tenggara. Parasitism rates varied from $1.50 \%$ in West Nusa Tenggara up to 59.18\% in East Java. Logistic regression revealed that probability of severe damage by the cassava mealybug was significantly $(\mathrm{P}<0.05)$ increased with the increasing abundance of ants.
\end{abstract}

Keywords: Anagyrus lopezi, geographic distribution, Phenacoccus manihoti

\section{INTRODUCTION}

Cassava mealybug, Phenacoccus manihoti MatileFerrero (Hemiptera: Pseudococcidae), is one the most important pests of cassava in the world (Bellotti et al. 1999). It is native to South America, but it was accidentally introduced into Africa in early 1970s (Nwanze 1982; Hennessey et al. 1990). Phenacoccus manihoti is parthenogenic, producing only female offspring. Hence, a single immature or adult is sufficient to start an outbreak. The pest spread throughout the cassava belt of Africa, sharply reducing cassava yields (Norgaard 1988). In the field, the mealybug spread by the wind and over large distances through the movement of infested plant materials. The pest feeds on the leaf near the growing point of the cassava plant. During feeding, the mealybug injects a toxin that causes leaf curling, slowing of shoot growth, and eventual leaf withering. Reduction of tuber yield loss of infested plants up to $84.4 \%$ and $54.4 \%$ were reported in late- and early- planted cassava, respectively (Nwanze 1982). To control the pest, a host-specific solitary endoparasitoid Anagyrus lopezi (De Santis) (Hymenoptera: Encyrtidae) was imported from Paraguay and released in Nigeria in 1981 (Herren and Lema 1982). The introduction of this parasitoid into Africa reduced mealybug infestation by $90 \%$, becoming a highly-successful case of classical biological control (Norgaard 1988).

Phenacoccus manihoti was not known to occur in Asia until 2008, when it was first detected in Thailand (Winotai et al. 2010; Parsa et al. 2012). Since that year, it has spread to others countries in Southeast Asia including Indonesia (Muniappan et al. 2011), Cambodia and Vietnam (Parsa et al. 2012), and Malaysia (Sartiami et al. 2015), caused serious damage to cassava production (Winotai et al. 2010; Bellotti et al. 2012). Phenacoccus manihoti poses a threat to the food security and livelihood of the poor farmers (Yonow et al. 2017). Following the success of classical biological control of the cassava mealybug in Africa, the parasitoid A. lopezi then was introduced into Thailand in 2009 and released at a nationwide scale in mid-2010 (Winotai et al. 2010). Anagyrus lopezi was subsequently introduced into neighboring countries, such as Laos and Cambodia (in 2011), Vietnam (in 2013) and Indonesia (in 2014) (Wyckhuys et al. 2014; Wyckhuys et al. 2018b).

Five years following the first detection in Bogor in 2010, P. manihoti has spread to almost all cassava growing areas in Java as well as in Lampung (Abdulchalek et al. 2017). Meanwhile, the introduced parasitoid A. lopezi which was released in Bogor in September 2014 has successfully established and survived under local climatic conditions. However, there is no information available on the distribution of $P$. manihoti outside of Java till now; and so establishment and spread of A. lopezi following field release have not been evaluated. Based on this background, research was conducted with the objectives to determine the geographic distribution of $P$. manihoti and its parasitoid A. lopezi in some of the major cassava growing areas in Indonesia. 


\section{MATERIALS AND METHODS}

\section{Field survey}

The field survey of $P$. manihoti and A. lopezi was carried out during the dry season of 2017 (OctoberNovember) and 2018 (September-October) in 80 cassava fields in Lampung ( $\mathrm{n}=11$ fields), Banten ( $\mathrm{n}=9$ fields), West Java ( $\mathrm{n}=9$ fields), Central Java ( $\mathrm{n}=9$ fields), East Java $(\mathrm{n}=12$ fields), West Nusa Tenggara $(\mathrm{n}=9$ fields), and East Nusa Tenggara $(\mathrm{n}=21$ fields). Survey protocols followed those that have been used in the region (Graziosi et al. 2016; Wyckhuys et al. 2018a; Le et al. 2018), and was focused on cassava fields having characteristics of monoculture, uniform age and a continuous planting throughout the year. We selected older fields (7-10 months of age) with a minimum size of 0.25 ha in the main cassava-growing areas of each province, with individual sites located at least $1 \mathrm{~km}$ apart. Five linear transects were randomly chosen per site, with ten plants (spaced about 0.8 m) sampled in each transect. By doing so, a total of 50 plants per field were assessed for the presence of mealybugs, parasitoids, predators, and ants as well as level of infestation. Field-level $P$. manihoti infestation was expressed as the proportion of plants infested (mealybug incidence), average number of $P$. manihoti per tip (mealybug abundance), and tip damage. In fieldidentification of mealybugs was based on morphological characteristics such as coloration and length of abdominal waxy filaments (Parsa et al. 2012). Ants were identified using the keys provided by Hashimoto (2010). Tip damage was categorized as follows: score $0=$ healthy plants, score 1 = slight curling of leaf margins, score $2=$ slight bunching of the tip, score $3=$ leaves curling and distortion of the tip (bunchy top), and $4=$ severe defoliation (Neuenschwander et al. 1989). Location and elevation of each cassava field were recorded using a handheld GPS unit (Garmin Ltd, Olathe, KS). Information on cassava varieties, field size, and age of plants were obtained by interviewing local field owners or farmers.

To asses parasitism rates of $A$. lopezi, a total of 20 mealybug-infested tips or bunchy tops were randomly collected from each field. The tips (approximately $10 \mathrm{~cm}$ each) were broken off and placed in sealed paper bags and stored in a cooler box and brought to laboratories (University of Flores, University of Cendana, University of Mataram, and the Bogor Agricultural University). Upon arrival to the laboratory, cassava tips were carefully examined, and number of nymphal instar-2, -3 , adults, and mummies of $P$. manihoti were counted. Further, cassava tips were placed separately within transparent plastic polyvinyl chloride $(\mathrm{PVC})$ container $(\mathrm{d}=8 \mathrm{~cm}, \mathrm{t}=11.3 \mathrm{~cm})$ and covered with a gauze cover. Samples were held in the laboratory at temperature $27-30^{\circ} \mathrm{C}$, relative humidity 65 $70 \%, 12: 12 \mathrm{~h}$ light-dark cycle, and observed daily for 3-4 weeks for parasitoid or hyperparasitoid emergence. Specimens were stored in Eppendorf tube with 70\% alcohol and labeled according to the alphanumeric code of the field samples for subsequent identification. Hyperparasitoid generic determinations were made using Hayat (1998). Level of parasitism was calculated by dividing the number of emerged parasitoids by the number of mealybugs per tip, and level hyperparasitism was calculated as the number of emerged hyperparasitoids divided by number of emerged primary parasitoids. Parasitism rates were computed for individual cassava tips, and average-field-level parasitism rates were calculated for each province. The sex of emerged A. lopezi wasps was determined and sex ratio was expressed as proportion of adults that were males.

\section{Data analysis}

All data from the fields were tabulated in MS. Excel consisting of latitude, longitude, elevation, abundance of mealybugs, predators, ants, parasitoids, the number of plants infested. Using Arc GIS version 10.41, a map of geographical distribution of $P$. manihoti and parasitoid $A$. lopezi was drawn. Field-level crop damage (I) by $P$. manihoti was calculated by the formula (Townsend and Heuberger 1943):

$$
I=\frac{\sum_{i=1}^{n=5} n_{i} \times v_{i}}{N \times V} \times 100 \%
$$

Where $n_{i}$ is the number of cassava tips with score $i, v_{i}$ is the value of score-i, $\mathrm{N}$ is the total number of cassava tips observed, and $\mathrm{V}$ is the highest score.

Following the calculation of I, field-level of crop damage is grouped into two categories: low-moderate damage $(I=1-50 \%)$ and severe damage $(I=51$ $100 \%)$. Logistic regression analysis was then used to model the relationship of a binary dependent variable (lowmoderate or severe damage) to independent variables using equation:

$$
P(I)=\frac{e^{b_{0}+b_{1} x_{1}+b_{2} x_{2}+b_{3} x_{3}+b_{4} x_{4}+b_{5} x_{5}}}{1+e^{b_{0}+b_{1} x_{1}++b_{2} x_{2}+b_{3} x_{3}+b_{4} x_{4}+b_{5} x_{5}}}
$$

Where: $\mathrm{P}(\mathrm{I})$ is the probability of crop damage $(0=$ low to moderate; $1=$ severe), $x$ is independent variables, $b_{0}$ is intercept and $b$ is coefficient of regression. The dependent variables incorporated into the models were elevation, abundance of $P$. manihoti, ants, predator Plesiochrysa ramburi Schneider (Neuroptera: Chrysopidae), and level of parasitism by A. lopezi. Logistic regression analysis was performed using SAS version 9.4.

\section{RESULTS AND DISCUSSION}

\section{Distribution and infestation of $P$. manihoti}

Based on the field survey, a total of four different mealybug species were recorded from cassava fields: $P$. manihoti, Paracoccus marginatus Williams \& Granara de Willink, Pseudococcus jackbeardsleyi Gimpel-Miller, and Ferrisia virgata Cockerell. Across sites, a total of 98.949 mealybugs were counted, with $P$. manihoti constituted $55.36 \%$, P. marginatus $31.89 \%, F$. virgata $8.67 \%$, and P. jackbeardsleyi $4.06 \%$. Phenacoccus manihoti has been found in all provinces surveyed (Figure 1). 


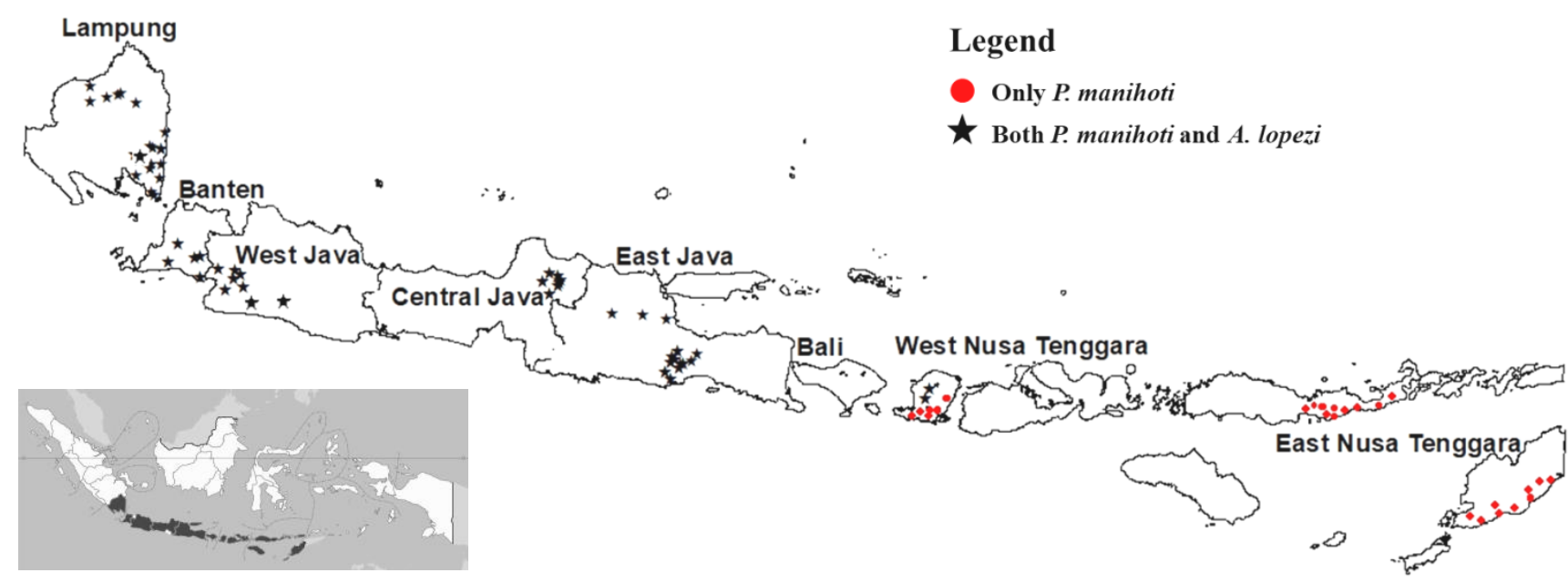

Figure 1. Map showing the geographical distribution of Phenacoccus manihoti and Anagyrus lopezi

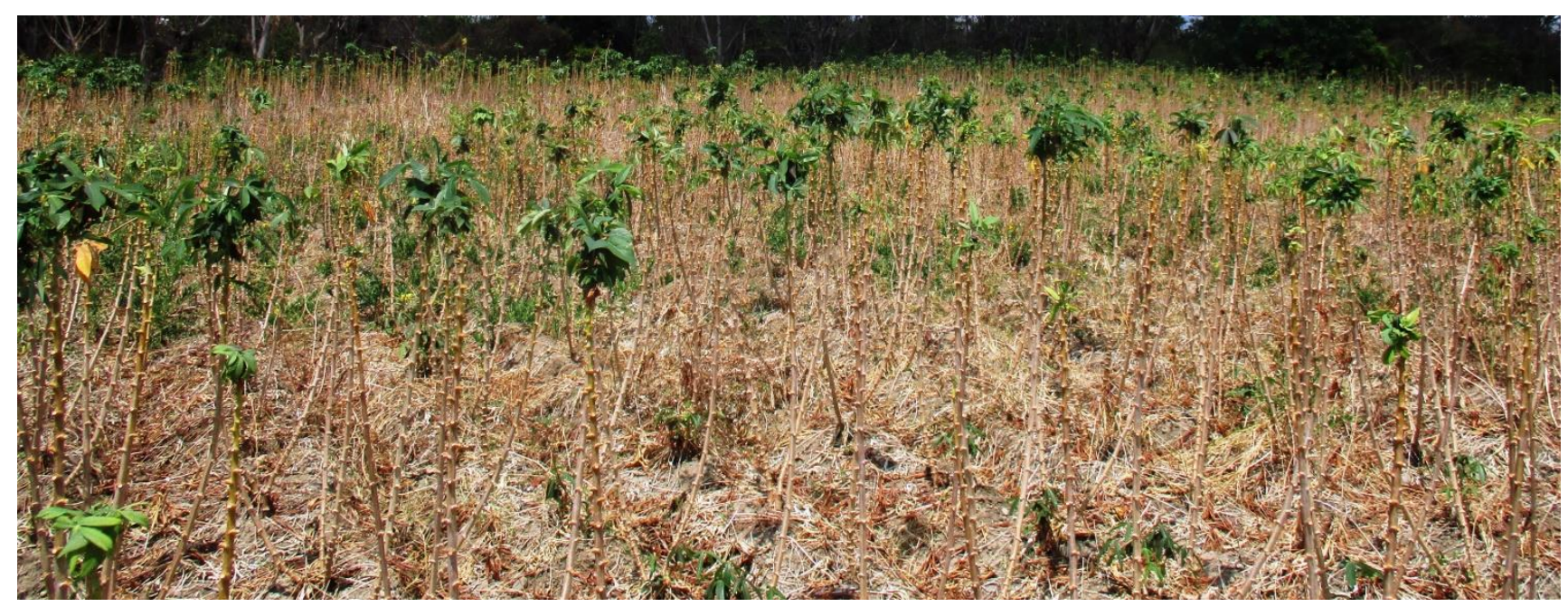

Figure 2. Cassava field severely infested by Phenacoccus manihoti with symptom of bunchy tops

Among 80 cassava field sites, the $P$. manihoti infestations were found in 77 sites $(95 \%)$ distributed in Lampung, Banten, West Java, Central Java, East Java, West Nusa Tenggara, and East Nusa Tenggara. More recently, $P$. manihoti was reported being present in Bangka (Nopriawansyah et al. 2019). Personal communication with other scientists (Hidrayani of Andalas University, West Sumatra and Adriani Ichsan of State University of Gorontalo, Gorontalo) suggested that P. manihoti has been found in West Sumatra as well as North Sulawesi.

The cassava mealybug attacked the terminal ends of cassava shoots, caused symptom of clustering and curling of top new leaves called "bunchy top". Further symptoms are stem distortion (shortening of the internodes) and severe defoliation. The symptoms of $P$. manihoti infestation were more commonly found in Lampung, East Nusa Tenggara and in West Nusa Tenggara, and occurred in a large area ( \pm 5 ha) at each location. Relatively higher infestation was noticed in East Nusa Tenggara were fields with bunchy tops (Figure 2) were widespread, and almost all of the plants had only a few leaves left intact.

Field-level incidence of $P$. manihoti (i.e. proportion of mealybug-affected tips) was high and ranged from $35.50 \%$ in Central Java up to $74.18 \%$ in Lampung (Table 1). Level of crop damage by the cassava mealybug varied from $15.12 \%$ in Central Java up to $44.05 \%$ in West Nusa Tenggara. Abundance of cassava mealybug ranged from 10.21 insects per tip in Lampung up to 43.89 insects per tip in East Nusa Tenggara. Le et al. (2018) reported that fieldlevel incidence of $P$. manihoti in Vietnam averaged $24.8 \%$ and mealybug abundance averaged 5.56 insects per tip. Higher infestation in some locations, especially in East Nusa Tenggara, was allegedly due to hot weather conditions and lack of intensive cassava cultivation. Ezumah and Knight (1978) demonstrated that dry weather, soil moisture stress, and soil erosion are some of the environmental factors that enhance the population build-up of P. manihoti. According to Iheagwam and Eluwa (1983), 
the population density of $P$. manihoti was usually high during the dry season and markedly reduced during rainy season. Rainfall is a key determinant of $P$. manihoti abundance and population dynamics: dry regions, years and seasons favor outbreaks (Gutierrez et al. 1988). In addition to hot weather conditions and low rainfall, population build-up of $P$. manihoti was also triggered by nutrientdeficient soil as result of lack of fertilization (Schulthess et al. 1997).

\section{Distribution and parasitism rate of $A$. lopezi}

Three years following the release, A. lopezi was found in Lampung, Java, and Lombok (see Figure 1). It can be assumed that $A$. lopezi has spread on its own or through winds from the release site in Bogor and passive transport by man of parasitized cassava mealybug on cassava cuttings from one district to another. Herren et al. (1987) reported that seven years following release in Nigeria, the parasitoid has established in 19 African countries and has spread over an area of over 1.5 million $\mathrm{km}^{2}$. The speed of dispersal of $A$. lopezi in Africa was $50-100 \mathrm{~km}$ in one dry season (5-8 months) (Herren et al. 1987). Lema and Herren (1985) reported that parasitoid A. lopezi has spread over a distance of about $150 \mathrm{~km}$ in 14 months.

Rate of parasitism of $A$. lopezi in each province varied, ranging from $1.50 \%$ (West Nusa Tenggara), up to $59.18 \%$ (East Java) (Table 2). The highest parasitism rate $(81.25 \%)$ was detected in Mojokerto Regency (East Java), as indicated by large number of mummified mealybugs found at the end of the dry season. Le et al. (2018) reported seasonal rate of parasitism in Vietnam averaged 49.9. $52.1 \%$. Sex ratio of $A$. lopezi in the field was generally male-biased. The proportion of male wasps was 0.69 in Lampung, 0.57 in Banten, 0.52 in West Java, 0.56 in Central Java, 0.61 in East Java, but 0.4 in Lombok (West
Nusa Tenggara). van Dijken et al. (1991) reported field sex ratio of $A$. lopezi in Africa varied from 0.44 at low cassava mealybug densities to highly male-biased of 0.70 at high host densities. Small hosts ( $2^{\text {nd }}$ instar nymph) are mainly used for the production of male offspring, whereas large hosts ( $3^{\text {rd }}$ instar nymph) are used for production of female offspring. Therefore, sex ratio (males to total parasitoids) increases with host density, since proportion of small hosts encountered in the field increases with increasing host density (van Dijken et al. 1991).

A total of 150 hyperparasitoids emerged from fieldcollected tips held in the laboratory, consisting of $56.7 \%$ Chartocerus sp. (Hymenoptera: Signiphoridae) and $43.3 \%$ Prochiloneurus sp. (Hymenoptera: Encyrtidae). Average hyperparasitism rates $(\mathrm{x} \pm \mathrm{SE})$ were $5.93 \pm 1.46 \%$ (Lampung), $0.13 \pm 0.12 \%$ (Banten), 3.29 $\pm 1.10 \%$ (West Java), $2.16 \pm 0.91 \%$ (Central Java), $4.89 \pm 1.32 \%$ (East Java), and $2.57 \pm 1.97 \%$ (West Nusa Tenggara). Le et al. (2018) reported three species of hyperparasitoids: Chartocerus sp. near walkeri Hayat, Prochiloneurus sp., and Promuscidea unfasciativentris Girault (Hymenoptera: Eriaporidae). In Vietnam, hyperparasitism rates were on average $2.79 \pm 5.38 \%$, with a maximum hyperparasitism rate of 26.4\% (Le et al. 2018). Hyperparasitoids associated with $A$. lopezi in Africa were Prochiloneurus insolitus (Alam) and Chartocerus hyalipennis (Hayat) (Neuenschwander et al. 1987). The rate of hyperparasitism in Togo varied considerably between 20-90\% (Agricola and Fischer 1991). In spite of high hyperparasitism, no detrimental effect on the control efficiency of $A$. lopezi was noticed (Neuenschwander and Hammond 1988; Agricola and Fischer 1991). Cage experiment showed that adding hyperparasitoids did not significantly reduce efficiency of A. lopezi in preventing plant damage (Goergen and Neuenschwander 1992).

Table 1. Infestation of cassava mealybug Phenacoccus manihoti at various field sites

\begin{tabular}{lcccc}
\hline Provinces & Number of field sites & $\begin{array}{c}\text { Mealybug incidence } \\
(\mathbf{\%}) *\end{array}$ & $\begin{array}{c}\text { Level of crop damage } \\
(\boldsymbol{\%}) *\end{array}$ & $\begin{array}{c}\text { Mealybug abundance (insects / } \\
\text { tip) } *\end{array}$ \\
\hline Lampung & 11 & $74.18 \pm 4.30$ & $25.57 \pm 1.87$ & $10.21 \pm 2.44$ \\
Banten & 9 & $36.00 \pm 9.67$ & $28.19 \pm 7.68$ & $17.78 \pm 4.14$ \\
West Java & 9 & $47.00 \pm 8.95$ & $18.69 \pm 2.33$ & $38.96 \pm 8.26$ \\
Central Java & 9 & $35.50 \pm 9.07$ & $15.12 \pm 5.51$ & $21.99 \pm 8.33$ \\
East Java & 12 & $38.67 \pm 6.20$ & $16.83 \pm 2.93$ & $21.61 \pm 4.86$ \\
West Nusa Tenggara & 9 & $57.56 \pm 5.57$ & $44.05 \pm 5.26$ & $37.33 \pm 3.58$ \\
East Nusa Tenggara & 21 & $54.67 \pm 7.10$ & $36.57 \pm 4.25$ & $43.89 \pm 4.67$ \\
\hline
\end{tabular}

Note: *Mean \pm SE

Table 2. Parasitism rate of Anagyrus lopezi and abundance of Phenacoccus manihoti and ants

\begin{tabular}{lcccc}
\hline Province & $\begin{array}{c}\text { Number of field } \\
\text { sites }\end{array}$ & $\begin{array}{c}\text { Parasitism rate } \\
(\boldsymbol{\%}) *\end{array}$ & $\begin{array}{c}\text { Abundance of } \\
\boldsymbol{P} \text {. ramburi (insects/tip)* }\end{array}$ & $\begin{array}{c}\text { Abundance of ants } \\
\text { (insects/tip)* }\end{array}$ \\
\hline Lampung & 11 & $50.85 \pm 3.67$ & $0.13 \pm 0.03$ & $1.04 \pm 0.42$ \\
Banten & 9 & $22.15 \pm 1.54$ & $0.10 \pm 0.03$ & $4.19 \pm 1.57$ \\
West Java & 9 & $17.01 \pm 4.01$ & $0.06 \pm 0.01$ & $4.06 \pm 2.51$ \\
Central Java & 9 & $24.17 \pm 7.92$ & $0.45 \pm 0.03$ & $1.01 \pm 0.04$ \\
East Java & 12 & $59.18 \pm 4.80$ & $0.26 \pm 0.09$ & $5.35 \pm 2.15$ \\
West Nusa Tenggara & 9 & $1.50 \pm 0.13$ & $0.19 \pm 0.04$ & $4.03 \pm 1.12$ \\
East Nusa Tenggara & 21 & $0.00 \pm 0.00$ & $0.29 \pm 0.06$ & $3.66 \pm 1.28$ \\
\hline
\end{tabular}

Note: *Mean \pm SE 
Table 3. Logistic regression analysis of the effect of elevation and biotic factors on level of crop damage by the cassava mealybug

\begin{tabular}{llcccc}
\hline Parameter & \multicolumn{1}{c}{$\begin{array}{c}\text { Independent } \\
\text { variable }\end{array}$} & $\begin{array}{c}\text { Estimated } \\
\text { parameter }\end{array}$ & SE & Wald $\chi^{2}$ & P value \\
\hline$b_{0}$ & Intercept & -5.51 & 1.53 & 56.91 & 0.000 \\
$b_{1}$ & Elevation & -0.00309 & 0.00245 & 1.72 & 0.190 \\
$b_{2}$ & P. manihoti & 0.1498 & 0.0418 & 32.92 & 0.000 \\
$b_{3}$ & Ants & 0.188 & 0.101 & 4.04 & 0.044 \\
$b_{4}$ & A. lopezi & -0.0122 & 0.0201 & 0.38 & 0.539 \\
$b_{5}$ & P. ramburi & -0.68 & 1.68 & 0.16 & 0.685 \\
\hline
\end{tabular}

\section{Green lacewing and ants}

Predatory insect generally found in the cassava fields during the surveys was a green lacewing Plesiochrysa ramburi (Walker) (Neuroptera: Chrysopidae). The density of larvae was low ranged $0.06-0.45$ individuals per tip (Table 2). Numerous eggs of $P$. ramburi were often observed on mealybug infested shoots. Wardani (2015) reported that $P$. ramburi is a natural enemy of cassava mealybug which was commonly found in cassava fields in Bogor. Sattayawong et al. (2016) also found P. ramburi as a dominant predatory insect in cassava fields in Thailand. Mealybug destroyer, Cryptolaemus montrouzieri Mulsant (Coleoptera: Coccinellidae) is often found in cassava fields infested by mealybugs, as previously reported by Wahyuningsih et al. (2019). Other insect species associated with cassava mealybug-infested plants were ants, which are attracted to honeydew excreted by mealybugs. The ants were identified as Dolichoderus thoracicus Smith, Anoplolepis gracilipes Smith, Tapinoma melanocephalum Fabricius, Camponotus sp., and Crematogaster sp. The density of ants varied between 1-5 individuals per tip (Table 2). In Africa, species of ants associated with the cassava mealybug were Camponotus, Crematogaster, and Pheidole (Cudjoe et al. 1993).

\section{Logistic regression}

The logistic regression analysis shows the coefficients $b_{1}$ (elevation), $b_{4}$ (parasitism rate of $A$. lopezi), and $b_{5}$ (abundance of $P$. ramburi) each with a negative sign (Table $3)$. This indicates that the probability of severe crop damage by $P$. manihoti decreases with the increasing of elevation, parasitism rate of $A$. lopezi, and abundance of predator $P$. ramburi. However, their effects are not statistically significant $(\mathrm{p}>0.05)$. This might be due to low abundance and high variability of $P$. ramburi larval population in the fields. In addition, $P$. ramburi generally arrived later on the growing $P$. manihoti populations when the pest has reached a peak and caused severe damage to cassava plants as previously observed by Wardani (2015). Meanwhile, A. lopezi is reported to be an effective and efficient parasitoid in reducing population of $P$. manihoti (Neuenschwander et al. 1989; Hammond and Neuenschwander 1990). A. lopezi is attracted to the mealybug even at the lowest host densities and reacted strongly to an increase in host density (Neuenschwander et al. 1989). The lack of significant effect of parasitoid $A$. lopezi on mealybug damage was due to the fact that our observations were limited only to parasitoid emergence (parasitism rate), whereas mortality of mealybug due to host-feeding and mutilation by A. lopezi was not observed. Neuenschwander and Madojemu (1986) reported that mealybug mortality caused by parasitoid host-feeding and mutilation generally occurs on the $1^{\text {st }}$ and $2^{\text {nd }}$ instar of mealybug nymphs. Therefore, although the parasitism rate in the field rarely exceeds 30\% (Lema and Herren 1985), mealybug mortality can be higher as a result of hostfeeding behavior of the parasitoid (Neuenschwander and Sullivan 1987). According to Neuenschwander and Madojemu (1986) mealybug mortality caused by host feeding and mutilation is a major component of the effectiveness of $A$. lopezi as a biological control agent for $P$. manihoti. However, this effect could not be measured in the field.

In contrast to the effect of $P$. ramburi and $A$. lopezi, the coefficient $b_{2}$ (abundance of $P$. manihoti) and $b_{3}$ (abundance of ants) each has a positive sign (Table 3), indicating that the probability of severe crop damage increases with the increasing abundance of $P$. manihoti as well as ants. Ants and mealybug form a mutualistic relationship. Mealybug produces honeydew as a food source for ants. In turn, ants visiting mealybug protect it against natural enemies such as predator and parasitoid (Helms and Vinson 2008). Therefore, a high population abundance of ants can indirectly increase the mealybug population, and subsequently, cause severe damage to plants.

\section{Challenges}

To date, several provinces have been invaded by $P$. manihoti, and it could impose a serious threat to the cassava production in yet uninvaded provinces. $P$. manihot $i$ has thelytokous parthenogenesis, so introduction of a single individual could be sufficient to lead to successful invasion. Moreover, ovisacs or eggs adhere to carriers, while nymphs and adults can spread with wind, facilitating long-distance dispersal (Parsa et al. 2012). In Africa, $P$. manihoti has been spreading at an alarming rate of $150 \mathrm{~km}$ per year (Winotai et al. 2010), compared to less than $30 \mathrm{~km}$ per year for other invasive hemipterans (Liebhol and Tobin 2008). Risk analysis for biological invasion indicates that almost all provinces in Indonesia are climatically suitable for P. manihoti (Yonow et al. 2017). Therefore, further surveys in other cassava growing provinces such as in Sumatra, Sulawesi, Maluku, and Papua are needed to map this pest distribution at a national scale. In addition to that, since A.lopezi has not been found in East Nusa Tenggara, it 
would be necessary to introduce the parasitoid into this area to control $P$. manihoti. Particularly for invasive pests, biological control constitutes an environmentally sound and cost-effective management option (Tancharoen et al. 2018). Parasitoid A. lopezi has exceptional dispersal potential, a high degree of adaptation to varying agro-ecological conditions, host-feeding capabilities and ability to persist at low P. manihoti densities (Neuenschwander et al. 1989), and thus is well-adapted to provide effective biological control in various settings of cassava productions (Le et al. 2018). Furthermore, especially in intensified cassava production, good agricultural practices should be followed. It has been shown that fertilizer inputs and suitable water management likely benefit biological control by boosting A. lopezi development and fitness (Wyckhuys et al. 2017).

In conclusion, $P$. manihoti has been spreading throughout Java, Sumatra and Nusa Tenggara. The introduced parasitoid A. lopezi has successfully established and spread to Lampung and Lombok. Relatively higher $P$. manihoti population and crop damage in East Nusa Tenggara were due to the absence of parasitoid A. lopezi in this region. Probability of severe damage was more in cassava fields inhabited by higher ant population.

\section{ACKNOWLEDGEMENTS}

This work was supported by the Ministry of Research, Technology and Higher Education of the Republic of Indonesia under "PMDSU Program". We would like to thank Dr. KAG Wyckhuys for initiating collaborative research and providing additional funding. We are grateful to Dr. Sri Wahyuni, Umbu Rebu, and Dr. Bambang Supeno for providing backstopping to site selection and facilitating and assisting field survey activities.

\section{REFERENCES}

Abdulchalek B, Rauf A, Pudjianto. 2017. Kutu putih singkong, Phenacocccus manihoti Matile-Ferrero (Hemiptera: Pseudococcidae): Persebaran Geografi di Pulau Jawa dan rintisan pengendalian hayati. J Hama Penyakit Tanaman Tropika 17: 1-8. [Indonesian]

Agricola U, Fischer HU. 1991. Hyperparasitism in two newly introduced parasitoids, Epidinocarsis lopezi and Gyranusoidea tebygi (Hymenoptera: Encyrtidae) after establishment in Togo. Bull Entomol Res 81: 127-132.

Bellotti A, Campo BVH, Hyman G. 2012. Cassava production and pest management: Present and potential threats in a changing environment. Trop Plant Biol 5: 39-72.

Bellotti A, Smith L, Lapointe SL. 1999. Recent advances in cassava pest management. Ann Rev Entomol 44: 343-370.

Cudjoe AR, Neuenschawander P, Copland MJW. 1993. Interference by ants in biological control of cassava mealybug Phenacoccus manihoti (Hemiptera: Pseudococcidae) in Ghana. Bull Entomol Res 83: 15 22.

Ezumah HC, Knight A. 1978. Some notes on the mealybug, Phenacoccus manihoti MAT-FERR. Incidence on manioc (Manihot esculenta) in Bas, Zaire. Proceedings of the International Workshop on the cassava mealybug, Phenacoccus manihoti MAT-FERR, Pseudococcidae. Inera-M'vuazi, Bas Zaire, 26-29 June 1978.

Goergen G, Neuenschwander P. 1992. A cage experiment with four trophic levels: cassava plant growth as influenced by cassava mealybug, Phenacoccus manihoti, its parasitoid Epidinocarsis lopezi, and the hyperparasitoid Prochiloneurus insolitus and Chartocerus hyalipennis. J Plant Dis Protect 99 (2): 182-190.
Graziosi I, Minato N, Alvarez E, Ngo DT, Hoat TX, Aye TM, Pardo JM, Wongtiem P, Wyckhuys KAG. 2016. Emerging pests and diseases of Southeast Asia cassava: a comprehensive evaluation of geographic priorities, management options and research needs. Pest Manag Sci 72: 1071-1089.

Gutierrez AP, Neuenschwander P, Schulthess F, Herren HR, Baumgaertner JU. 1988. Analysis of biological control of cassava pests in Africa. II. Cassava mealybug, Phenacoccus manihoti. J Appl Ecol 25: 921-940.

Hammond WNO, Neuenschwander P. 1990. Sustained biological control of the cassava mealybug Phenacoccus manihoti (Hom.: Pseudococcidae) by Epidinocarsis lopezi (Hym.: Encyrtidae). Entomophaga. 35 (4): 515-526.

Hashimoto Y. 2010. Identification guide to the ant genera of Borneo: Inventory and collection. UMS-BBEC Press, Kota Kinabalu, Malaysia.

Hayat M. 1998. Aphelinidae of India (Hymenoptera: Chalcodoidea): a taxonomic revision. Memoirs on Entomology International. Associated Publishers, Gainesville, FL.

Helms KR, Vinson SB. 2008. Plant resources and colony growth in an invasive ant: the importance of honeydew-producing hemipteran in carbohydrate transfer across trophic levels. Environ Entomol 37: 487493.

Hennessey RD, Neuenschwander P, Muaka T. 1990. Spread and current distribution of the cassava mealybug, Phenacoccus manihoti (Homoptera: Pseudococcidae), in Zaire. Trop Pest Manag 36 (2): 103 107.

Herren HR, Lema KM. 1982. CMB - first successful releases. Commonw Agric Bur 3: 18.

Herren HR, Neuenschwander P, Hennessey RD, Hammond WNO. 1987. Introduction and dispersal of Epidinocarsis lopezi (Hym., Encyrtidae), an exotic parasitoid of the cassava mealybug, Phenacoccus manihoti (Hom., Pseudococcidae), in Africa. Agric Ecosys Environ 19: 131-144.

Iheagwam EU, Eluwa MC. 1983. The effects of temperature on the development of the immature stages of the Cassava Mealybug, Phenacoccus manihoti Mat-Ferr. (Homoptera, Pseudococcidae). Deut Entomol Z 30: 17- 22.

Le TTN, Graziosi I, Cira TM, Gates MW, Parker L, Wyckhuys KAG. 2018. Landscape context does not constrain biological control of Phenacoccus manihoti in intensified cassava systems of southern Vietnam. Biol Control 121: 129-139.

Lema, KM, Herren HR. 1985. Release and establishment in Nigeria of Epidinocarsis lopezi a parasitoid of the cassava mealybug, Phenacoccus manihoti. Entomol Exp Appl 38: 171-175.

Liebhold AM, Tobin PC. 2008. Population ecology of insect invasions and their management. Ann Rev Entomol 53: 387-408.

Muniappan R, Shepard BM, Watson W, Carner GR, Rauf A, Sartiami D, Hidayat P, Afun JVK, Goergen G, Ziaur AKM. 2011. New record of invasive insects (Hemiptera: Sternorrhyncha) in Southeast Asia and West Africa. J Agric Urban Entomol 26 (4): 167-174.

Neuenschwander P, Hammond WNO. 1988. Natural enemy activity following the introduction of Epidinocarsis lopezi (Hymenoptera: Encyrtidae) against the cassava mealybug, Phenacoccus manihoti (Homoptera: Pseudococcidae). Entomol Soc Amer 17 (5): 894-902.

Neuenschwander P, Hennessey RD, Herren HR. 1987. Food web of insects associated with cassava mealybug, Phenacoccus manihoti Matile-Ferrero (Hemiptera: Pseudococcidae), and its introduced parasitoid Epidinocarsis lopezi (De Santis) (Hymenoptera: Encyrtidae), in Africa. Bull Entomol Res 77: 177-189.

Neuenschwander P, Madojemu E. 1986. Mortality of the cassava mealybugs, Phenacoccus manihoti MAT-FERR. (Hom., Pseudococcidae), associated with an attack by Epidinocarsis lopezi (Hym.: Encyrtidae). Bull de la Societe Entomologique Suisse 59: 5762.

Neuenschwander P, Sullivan D. 1987. Interactions between the endophagous parasitoid Epidinocarcis lopezi and its host, Phenacoccus manihoti. Insect Sci Applic 8 (4/5/6): 857-859.

Neuenschwander P, Hammond WNO, Gutierrez AP, Cudjoe AR, Adjaklo e R, Baumgärtner JU, Regev U. 1989. Impact assessment of the biological control of the cassava mealybug, Phenacoccus manihoti Matile Ferrero (Hemiptera: Pseudococcidae) by the introduced parasitoid Epidinocarsis lopezi (De Santis) (Hymenoptera: Encyrtidae). Bull Entomol Res 79: 579-594.

Nopriawansyah N, Rauf A, Kusumah YM, Nurmansyah A, Koesmaryono Y. 2019. Genetic variation among the geographic population of 
cassava mealybug, Phenacoccus manihoti (Hemiptera: Pseudococcidae), in Indonesia inferred from mitochondrial COI gene sequence. Biodiversitas 20 (9): 1685-1692.

Norgaard RB. 1988. The biological control of cassava mealybug in Africa. Am J Agr Econ 70: 366-371.

Nwanze KF. 1982. Relationships between cassava root yields and crop infestations by the mealybug, Phenacoccus manihoti. Trop Pest Manag 28: 27-32.

Parsa S, Kondo T, Winotai A. 2012. The cassava mealybug (Phenacoccus manihoti) in Asia: First records, potential distribution, and an identification key. PLoS ONE 7 (10): e47675. DOI 10.1371/journal.pone.0047675.

Sartiami D, Watson GW, Roff MMN, Hanifah MA, Idris AB. 2015. First record of cassava mealybug, Phenacoccus manihoti (Hemiptera: Pseudococcidae) in Malaysia. Zootaxa 3957 (2): 235-238.

Sattayawong C, Uraichuen S, Suasa-ard W. 2016. Larval preference and performance of the green lacewing, Plesiochrysa ramburi (Schneider) (Neuroptera: Chrysopidae) on three species of cassava mealybugs (Hemiptera: Pseudococcidae). Agri Nat Resour 50: 460-464.

Schulthess F, Neuenschwander P, Gounou S. 1997. Multi-trophic interactions in cassava, Manihot esculenta, cropping systems in the subhumid tropics of West Africa. Agric Ecosys Environ 66: 211-22.

Thancharoen A, Lankaew S, Moonjuntha $\mathrm{P}$, Wongphanuwat $\mathrm{T}$, Sangtongpraow B, Ngoenklan R, Kittipadakul P, Wyckhuys KAG. 2018. Effective biological control of an invasive mealybug pest enhances root yield in cassava. J Pest Sci 91: 1199-1211.

Townsend GR, Heuberger JW. 1943. Methods for estimating losses caused by diseases in fungicide experiments. Plant Dis Rep 27: 340343.

van Dijken MJ, Neuenschwander P, van Alphen JJM, Hammond WNO. 1991. Sex ratios in field populations of an exotic parasitoid of the cassava mealybug in Africa. Ecol Entomol 16: 233-240.
Wahyuningsih E, Rauf A, Santoso S. 2019. Biologi, neraca hayati, dan pemangsaan Cryptolaemus montrouzieri Mulsant (Coleoptera: Coccinellidae) pada Paracoccus marginatus Williams \& Granara de Willink (Hemiptera: Pseudococcidae). J Entomol Indo 16 (1): 18-28.

Wardani N. 2015. Kutu putih ubi kayu Phenacoccus manihoti MatileFerrero (Hemiptera: Pseudococcidae). Hama invasive baru di Indonesia [Disertasi]. Institut Pertanian Bogor, Bogor. [Indonesian]

Winotai A, Goergen G, Tamo M, Neuenchwander P. 2010. Cassava mealybug has reached Asia. Biocontrol News Inform 31: 10-11.

Wyckhuys KAG, Burra DD, Tran DH, Graziosi I, Walter AJ, Nguyen TG, Trong HN, Le BV, Le, TTN, Fonte SJ. 2017. Soil fertility regulates invasive herbivore performance and top-down control in tropical agroecosystems of Southeast Asia. Agr Ecosyst Environ 249: 38-49.

Wyckhuys KAG, Rauf A, Ketelaar J. 2014. Parasitoid introduced into Indonesia: part of a region-wide campaign to tackle emerging cassava pests and diseases. Biocontrol News Inform 35 (4): 35-37.

Wyckhuys KAG, Wongtiem P, Rauf A. Thancharoen A, Heimpel GE, Le NTT, Fanani MZ, Gurr GM, Lundgren JG, Burra DD, Palao LK, Hyman G, Graziosi I, Le VX, Mock MJW, Tscharntke T, Wratten SD, Nguyen LV, You M, Lu Y, Ketelaar JW, Goergen G, Neuenschwander P. 2018a. Continental-scale suppression of an invasive pest by a host-specific parasitoid underlines both environmental and economic benefits of arthropod biological control. PeerJ 6: e5796; DOI: 10.7717/peerj.5796.

Wyckhuys KAG, Zhang W, Prager SD, Kramer DB, Delaquis E, Gonzalez CE, van der Werf W. 2018b. Biological control of invasive pest eases pressures on global commodity markets. Environ Res Lett 13: $1-13$.

Yonow T, Kriticos DJ, Ota N. 2017. The potential distribution of cassava mealybug (Phenacoccus manihoti), a threat to food security for the poor. PLoS ONE 12 (3): e0173265. DOI: 10.1371/journal.pone. 0173265 . 